\title{
Does a penetrating diaphragm injury have an effect on morbidity and mortality?
}

\author{
Penetran diyafram yaralanması morbidite ve mortaliteyi etkiler mi?
}

\author{
Bünyami ÖZOĞUL, ${ }^{1}$ Abdullah KISAOĞLU, ${ }^{1}$ Gürkan ÖZTÜRK, ${ }^{1}$ Sabri Selçuk ATAMANALP, ${ }^{1}$ \\ Yener AYDIN, ${ }^{2}$ Bülent AYDINLI, ${ }^{1}$ Mehmet İlhan YILDIRGAN ${ }^{1}$
}

\section{BACKGROUND}

In this study, we investigated the diaphragmatic ruptures that accompanied penetrating abdominal injury.

\section{METHODS}

Records of 237 patients with penetrating abdominal trauma seen in the General Surgery Clinic between January 1996 and December 2010 were investigated retrospectively. Patients without diaphragmatic rupture were allocated to Group I and those with were allocated to Group II.

\section{RESULTS}

Diaphragmatic injury was not present in 177 patients and present in 60 patients. Diaphragmatic injury was on the right side in 12, left side in 41, and bilateral in 7. Eleven had thoracic herniation, and the most common hernia contents were the colon, stomach, greater omentum, small bowel, and spleen. The postoperative complication rate was $50 \%$ in Group I $(n=89)$ and $47 \%$ in Group II $(n=28)$, and there was no significant difference between the two groups $(\mathrm{p}>0.05)$. The length of hospital stay was slightly increased in Group II, but not significant ( $\mathrm{p}>0.05)$. Seventeen patients $(9.6 \%)$ in Group I and four patients $(6.6 \%)$ in Group II died. The difference in mortality rates between the two groups was not significant ( $\mathrm{p}>0.05)$.

\section{CONCLUSION}

Diaphragmatic rupture is not common among patients with penetrating abdominal trauma. There was no difference between patients with penetrating injuries and with versus without diaphragmatic injuries in terms of mortality and morbidity.

Key Words: Diaphragmatic injury; morbidity; mortality.

\section{AMAÇ}

$\mathrm{Bu}$ çalışmada penetran karın hasar ile birlikte olan diyafram yaralanmaları incelendi.

\section{GEREÇ VE YÖNTEM}

Bu çalışmaya Ocak 1996- Aralık 2010 tarihleri arasında genel cerrahi kliniğinde penetran karın travmalı 237 hastanın kayıtları geriye dönük olarak incelendi. Diyafram yırtığı olmayan hastalar Grup I, diyafram yırtığı olan hastalar Grup II olarak ayrıldı.

\section{BULGULAR}

Hastaların 177'sinde diyafram hasarı yoktu ve 60 hastada ise diyafram hasarı vardı. Diyafram hasarı hastaların 12'sinde sağda, 7'sinde iki taraflı ve 41'inde sol tarafta idi. 11 olguda toraksa fitıklaşma vardı ve en fazla kolon, mide, omentum, ince bağırsaklar ve dalak torakal kaviteye fitıklaşıyordu. Ameliyat sonrası komplikasyon oranı Grup I'de \%50 (n=89) ve Grup II'de \%47 (n=28) idi. Her iki grup arasında istatistiksel olarak anlamlı bir fark yoktu ( $>00,05)$. Hastanede kalış süresi Grup II'de az miktarda fazla olmasına rağmen anlamlı bir fark yoktu $(p>0,05)$. Grup I'de 17 hasta $(\% 9,6)$ ve Grup II'de 4 hasta $(\% 6,6)$ hayatını kaybetti. Mortalite hızları iki grup arasında anlamlı değil idi $(\mathrm{p}>0,05)$.

\section{SONUÇ}

Penetran karın travmalı hastalarda diyafram yırtılması yaygin değildir. Penetran yaralanmalarda diyafram yaralanmas1 olan hastalarla olmayan hastalar arasinda fark bulunamamıştır.

Anahtar Sözcükler: Diyafram yaralanması; morbidite; mortalite. 
Diaphragmatic rupture (DR) is a commonly discussed problem in abdominal trauma. Injuries of the diaphragm associated with blunt abdominal trauma can complicate the course of the patient because of difficulty in the diagnosis and delayed intervention. Several publications report that diaphragmatic injuries in blunt abdominal trauma can have significant morbidity and mortality rates. ${ }^{[1]}$ In penetrating abdominal injuries, however, the contribution of diaphragmatic injuries to the mortality and morbidity is not clarified.

We report herein our diaphragmatic injury cases associated with penetrating abdominal injury.

\section{MATERIALS AND METHODS}

The records of 398 cases admitted to our clinic, Ataturk University Medical School, Department of General Surgery, with the diagnosis of penetrating abdominal trauma between January 1996 and December 2010 were evaluated retrospectively. The charts of 83 patients were excluded because of inadequate information. Penetrating abdominal trauma index (PATI) score was defined according the description from Moore et al. ${ }^{[2]}$ Patients who had a PATI score lower than 15 or higher than 50 were also excluded. Patients were divided in two groups. Group I consisted of patients without DR, while Group II consisted of patients with DR. The age, sex, mechanism of trauma (gunshot wound (GSW) or stab wound), injured organs, PATI score, presence, site and length of diaphragmatic injury, presence of hemo-pneumothorax, postoperative complications, length of hospital stay (LOS), and morbidity were recorded. Postoperative complications, LOS and morbidity were compared between the two groups. In Group II, the patients were further divided in two subgroups according to the length of the rupture. Patients with a rupture of $<5 \mathrm{~cm}$ were grouped as Group IIa and those with a rupture of $>5 \mathrm{~cm}$ were grouped as Group IIb. Postoperative complications, LOS and morbidity were compared between these two subgroups.

\section{Statistical analysis}

Results are presented as means $\pm \mathrm{SD}$, medians, or percentages. Analysis of variance and post hoc tests were used to compare continuous variables, and exact tests were used to compare proportions. A correlation coefficient was calculated using Spearman's rho. The Statistical Package for the Social Sciences (SPSS) version 12.0 (SPSS Inc, Chicago, IL) was used for analysis. A p value of 0.05 was considered statistically significant. All tests were two-tailed.

\section{RESULTS}

The records of 315 patients who were operated for penetrating abdominal trauma at Ataturk University Medical School, Department of General Surgery, with the diagnosis of penetrating abdominal trauma between January 1996 and December 2007 were reviewed. From these patients, 237 had a PATI score higher than 15. Diaphragmatic injury was not present in 177 of these patients (Group I) and present in the remaining 60 (Group II). Table 1 shows the age, sex, mechanism of trauma (GSW or stab wound), injured organs, PATI score, postoperative complications, LOS, and morbidity of the two groups. Table 2 shows the comparison of postoperative complications, LOS and morbidity between the two subgroups of patients with diaphragmatic injuries, consisting of patients with DRs $<5 \mathrm{~cm}$ (Group IIa) and $>5 \mathrm{~cm}$ (Group IIb).

In Group II (patients with diaphragmatic injury), diaphragmatic injuries were located on the right side in 12 cases, both sides (right and left) in 7 cases and on the left side in 41 cases. The size of the diaphragmatic defect varied between $1 \mathrm{~cm}$ and $12 \mathrm{~cm}$ (mean 4.6 $\mathrm{cm}$ ). There were $29 \mathrm{DRs}>5 \mathrm{~cm}$ long (Group IIb). In 11 cases, there was partial or total herniation of some intraabdominal organs, including the colon, stomach, greater omentum, small intestines, and spleen, into the thoracic cavity. All herniations were uncomplicated and there was no gangrene or circulatory problems in the herniated organs. All herniations occurred in Group IIb. No further resections or surgical treatments were necessary for the herniated organs. All DRs were primarily repaired. In 31 cases, a chest tube was placed to treat hemo-pneumothorax accompanying the diaphragmatic injury. The daily amount of chest tube drainage was between $50 \mathrm{cc}$ and $420 \mathrm{cc}$ (mean $260 \mathrm{cc}$ ). Chest tubes were removed in a median of 4 days. There were no problems with the pulmonary parenchyma or the mediastinal organs. There were also no open thoracostomies or re-operations because of hemo-pneumothorax.

The statistical analysis revealed that there was no statistical difference in age, gender, mechanism of injury, or mean PATI score between Groups I and II. There was also no difference in the involved organs ( $\mathrm{p}>0.05$ for all).

The overall complication rates were $50 \%$ (89 patients) and 47\% (28 patients) in Group I and Group II, respectively. The most common complications were infectious complications (wound infection, pulmonary infection, sepsis, intraabdominal abscess); others included wound dehiscence, pulmonary embolism and anastomotic leakage. When compared statistically, there were no differences in postoperative complications between the two groups $(\mathrm{p}>0.05)$. The comparison of complication rates of the two subgroups (Groups IIa and IIb) also revealed no significant difference.

The length of hospitalization (LOS) in the two groups was similar, with a slight increase in Group II, but the difference was not statistically significant 
Table 1. Age, sex, mechanism of trauma, injured organs, PATI score, postoperative complications, LOS, and morbidity according to groups

\begin{tabular}{lcc}
\hline & $\begin{array}{c}\text { Group I } \\
(\mathrm{n}=177)\end{array}$ & $\begin{array}{c}\text { Group II } \\
(\mathrm{n}=60)\end{array}$ \\
\hline Age (Mean / Years) & 44.6 & 44.1 \\
Gender (Female / Male) & $30 / 147$ & $9 / 51$ \\
Gunshot wound & $105(59.3 \%)$ & $43(71.6 \%)$ \\
Stab wound & $72(40.7 \%)$ & $17(28.4 \%)$ \\
PATI score (Mean) & 24.5 & 23.3 \\
Injured organs & & \\
$\quad$ Liver & $69(38.9 \%)$ & $32(53.3 \%)$ \\
$\quad$ Small intestine & $101(57 \%)$ & $21(35 \%)$ \\
$\quad$ Colon & $79(44.6 \%)$ & $13(21.6 \%)$ \\
$\quad$ Spleen & $41(23.1 \%)$ & $13(21.6 \%)$ \\
$\quad$ Stomach & $35(19.7 \%)$ & $15(25 \%)$ \\
$\quad$ Pancreas & $17(9.6 \%)$ & $5(8.3 \%)$ \\
$\quad$ Kidney and urinary & $29(16.4 \%)$ & $9(15 \%)$ \\
$\quad$ Major vascular & $24(13.5 \%)$ & $5(8.3 \%)$ \\
$\quad$ Other & $45(25.4 \%)$ & $21(35 \%)$ \\
Postoperative complications & $89(50 \%)$ & $28(47 \%)$ \\
(overall rate) & & \\
Infectious & $13 \%)$ \\
$\quad$ Wound infection & $69(38.9 \%)$ & $23(38.3 \%)$ \\
$\quad$ Pulmonary infections & $43(24.2 \%)$ & $14(23.3 \%)$ \\
$\quad$ Sepsis & $10(5.6 \%)$ & $5(8.3 \%)$ \\
Intraabdominal abscess & $8(4.5 \%)$ & $2(3.3 \%)$ \\
Wound dehiscence & $8(4.5 \%)$ & $2(3.3 \%)$ \\
Pulmostomotic leakage & $16(9 \%)$ & $4(6.6 \%)$ \\
Mortality & $3(1.6 \%)$ & $1(1.6 \%)$ \\
LOS (Days) & $1(0.5 \%)$ & - \\
PATI : Penetrating abdominal trauma index; LOS: Length of hospital stay.
\end{tabular}

( $>0.05$ ). There was also no statistically significant difference in the LOS between the two subgroups (Group IIa, Group IIb) of Group II.

A total of 17 patients $(9.6 \%)$ in Group I and 4 patients $(6.6 \%)$ in Group II died. Mortalities were not statistically different $(\mathrm{p}>0.05)$. The mortality rate was also not different between the two subgroups (Group IIa, Group IIb) of Group II.

\section{DISCUSSION}

Diaphragmatic injury is not common among abdominal trauma patients, with an incidence varying between $4-12 \% \cdot{ }^{[3,4]}$ The incidence of penetrating DR is reported to be $10-15 \% .{ }^{[5]}$ The importance of diaphragmatic injuries has been mentioned several times by different publications. ${ }^{[3,6]}$ The most common reported adverse outcome in this injury is the herniation of intraabdominal organs into the thoracic cavity. ${ }^{[6]}$ Therefore, the most commonly discussed aspects of this
Table 2. Length of hospital stay and morbidity between the two subgroups of patients with diaphragmatic injuries

\begin{tabular}{|c|c|c|}
\hline & $\begin{array}{l}\text { Group IIa } \\
(\mathrm{n}=31)\end{array}$ & $\begin{array}{c}\text { Group IIb } \\
(\mathrm{n}=29)\end{array}$ \\
\hline $\begin{array}{l}\text { Postoperative complications } \\
\text { (overall rate) }\end{array}$ & $15(48.3 \%)$ & $13(44.8 \%)$ \\
\hline Infectious & $13(41.9 \%)$ & $10(34.4 \%)$ \\
\hline Wound infection & $8(25.8 \%)$ & $6(20.6 \%)$ \\
\hline Pulmonary infections & $3(9.6 \%)$ & $2(6.8 \%)$ \\
\hline Sepsis & $1(3.2 \%)$ & $1(3.4 \%)$ \\
\hline Intraabdominal abscess & $1(3.2 \%)$ & $1(3.4 \%)$ \\
\hline Wound dehiscence & $3(9.6 \%)$ & $1(3.4 \%)$ \\
\hline Anastomotic leakage & $1(3.2 \%)$ & - \\
\hline Pulmonary embolism & - & - \\
\hline LOS (days) & $14.9 \pm 6.5$ & $13.2 \pm 6$ \\
\hline
\end{tabular}

LOS: Length of hospital stay.

injury are the difficulties in diagnosis and subsequent problems secondary to misdiagnosis and the early diagnosis of diaphragmatic injuries, especially in blunt trauma victims who will not be operated. ${ }^{[3,4,6]}$

We performed this study to determine the importance of a diaphragmatic injury that is detected during an emergent operation for penetrating abdominal injury. To make the groups comparable, we used PATI scoring and excluded patients with low and high PATI scores. Furthermore, to determine if the length of diaphragmatic injury is important, we divided the patients in two groups according the length of the injury $(<5 \mathrm{~cm}$ or $>5 \mathrm{~cm})$. We actually performed this study to show that diaphragmatic injury is harmless when it is detected during the operation and repaired properly.

About $50 \%$ of all diaphragmatic injuries cannot be detected during a routine investigation of trauma patients. They are mostly detected during an exploration for immediate operation of the trauma patient. ${ }^{[4,7]}$ Clinical findings of DR are not specific. Thoracic and abdominal symptoms may be minimal or even absent, and patients may not present with symptoms for months to years after the trauma. ${ }^{[8]}$

It is reported that penetrating diaphragmatic injuries are accompanied by at least two or three associated injuries, and patients are operated for these injuries. [9] Therefore, during a routine exploration of the abdominal cavity in a patient with penetrating abdominal trauma, especially when the injury is located in the upper abdomen, the diaphragm must be observed and even explored..$^{[4,5,7]}$

The most important adverse outcome of DR is the herniation of intraabdominal organs into the thoracic cavity. The incidence of herniation of intraabdominal 
organs into the pleural cavity is $58 \%$ in left-sided and $19 \%$ in right-sided DRs. ${ }^{[10-12]}$ In our series, the herniation rate was $18.3 \%$. We also observed that all herniations occurred in patients who had a DR length $>5$ $\mathrm{cm}$. Herniations can have an acute onset by causing symptoms arising from both the herniated intraabdominal organs as well as the thoracic organs that are compressed by the herniated organ. This subsequently results in symptoms related with circulatory problems or obstruction of the herniated organs, or dyspnea, cyanosis or cardiac compromise due to compression of the hernia. ${ }^{[13]}$ Furthermore, herniations may not become symptomatic until months or years after the trauma. ${ }^{[14,15]}$

Once detected, treatment is not complex. The operative treatment of diaphragmatic injury can be done by either primary suture repair or replacement with prosthetic materials if needed. It is a simple treatment and can be done with open surgical approach or laparoscopically. ${ }^{[16]}$

Most of the complications are associated with the adverse outcomes of DR. However, there is little information about the DR that is uncomplicated and treated during the exploration. Is this injury important, and could the presence of diaphragmatic injury complicate the postoperative course of a trauma patient? Theoretically it could. The impairment of diaphragmatic movements during respiration could impair normal breathing and cause atelectasia and associated pulmonary infections. ${ }^{[17]}$

The comparison of the two groups showed that there was no difference in the postoperative complications, LOS or mortality. We tried to create a homogeneous group, and therefore used the PATI score. This shows that diaphragmatic injuries that were diagnosed and repaired during the operation did not increase the complications, LOS or mortality. The complications in both groups were the same, and infectious complications were seen most commonly. In patients with diaphragmatic injuries, the incidence of pulmonary complications was not different from that in patients without diaphragmatic injuries.

Although 31 patients in Group II had tube thoracostomy, this did not influence the postoperative complication rate or LOS. Chest drains were applied to only 31 radiologically detected hemopneumothorax cases. In other cases, diaphragms were closed totally intraoperatively while the lungs were held at inspiration by the anesthetist. Postoperative chest drain was not needed in these cases. None of the patients had pleural contamination, and empyema did not occur in any case.

In conclusion, DR is not common in patients with penetrating abdominal trauma, but can be life-threat- ening when overlooked. It is important to keep in mind that diaphragmatic injury can associate with penetrating injury of intraabdominal organs, and thus routine observation of the diaphragm is necessary. When detected, the penetrating diaphragmatic injury does not influence the outcome.

Conflict-of-interest issues regarding the authorship or article: None declared.

\section{REFERENCES}

1. Turhan K, Makay O, Cakan A, Samancilar O, Firat O, Icoz $\mathrm{G}$, et al. Traumatic diaphragmatic rupture: look to see. Eur J Cardiothorac Surg 2008;33:1082-5.

2. Moore EE, Dunn EL, Moore JB, Thompson JS. Penetrating abdominal trauma index. J Trauma 1981;21:439-45.

3. Steinau G, Bosman D, Dreuw B, Schumpelick V. Diaphragmatic injuries--classification, diagnosis and therapy. [Article in German] Chirurg 1997;68:509-12. [Abstract]

4. Wirbel RJ, Mutschler WE. Right-sided diaphragmatic rupture with intrathoracic displacement of the entire right lobe of the liver. [Article in German] Unfallchirurg 1997;100:24952. [Abstract]

5. Mihos P, Potaris K, Gakidis J, Paraskevopoulos J, Varvatsoulis $\mathrm{P}$, Gougoutas B, et al. Traumatic rupture of the diaphragm: experience with 65 patients. Injury 2003;34:169-72.

6. Balkan ME, Kara M, Oktar GL, Unlü E. Transdiaphragmatic intercostal hernia following a penetrating thoracoabdominal injury: report of a case. Surg Today 2001;31:708-11.

7. Sadeghi N, Nicaise N, DeBacker D, Struyven J, Van Gansbeke D. Right diaphragmatic rupture and hepatic hernia: an indirect sign on computed tomography. Eur Radiol 1999;9:972-4.

8. Eren S, Kantarci M, Okur A. Imaging of diaphragmatic rupture after trauma. Clin Radiol 2006;61:467-77.

9. Arak T, Solheim K, Pillgram-Larsen J. Diaphragmatic injuries. Injury 1997;28:113-7.

10. Wirbel RJ, Mutschler W. Blunt rupture of the right hemi-diaphragm with complete dislocation of the right hepatic lobe: report of a case. Surg Today 1998;28:850-2.

11. Boulanger BR, Milzman DP, Rosati C, Rodriguez A. A comparison of right and left blunt traumatic diaphragmatic rupture. J Trauma 1993;35:255-60.

12. Tribble JB, Julian S, Myers RT. Rupture of the liver and right hemidiaphragm presenting as right hemothorax. J Trauma 1989;29:116-8.

13. Reina A, Vidaña E, Soriano P, Orte A, Ferrer M, Herrera E, et al. Traumatic intrapericardial diaphragmatic hernia: case report and literature review. Injury 2001;32:153-6.

14. Kozak O, Mentes O, Harlak A, Yigit T, Kilbas Z, Aslan I, et al. Late presentation of blunt right diaphragmatic rupture (hepatic hernia). Am J Emerg Med 2008;26:638.e3-5.

15. Mihos P, Potaris K, Gakidis J, Paraskevopoulos J, Varvatsoulis $\mathrm{P}$, Gougoutas B, et al. Traumatic rupture of the diaphragm: experience with 65 patients. Injury 2003;34:169-72.

16. Adesanya AA, da Rocha-Afodu JT, Ekanem EE, Afolabi IR. Factors affecting mortality and morbidity in patients with abdominal gunshot wounds. Injury 2000;31:397-404.

17. Schneider C, Tamme C, Scheidbach H, Delker-Wegener S, Köckerling F. Laparoscopic management of traumatic ruptures of the diaphragm. Langenbecks Arch Surg 2000;385:118-23. 